\title{
SUBLINGVALINIO IR INTRAVAGINALINIO MISOPROSTOLIO NAUDOJIMO GIMDYMUI SUŽADINTI PALYGINIMAS
}

\author{
Kornelija Mačiulienė $\dot{1}^{1}$ Dalytė Variakojienė ${ }^{1}$, Alesia Boukun ${ }^{2}$, Juliana Andreičik ${ }^{2}$ \\ ${ }^{1}$ Vilniaus gimdymo namai, ${ }^{2}$ Vilniaus universiteto Medicinos fakulteto \\ Akušerijos ir ginekologijos klinika
}

Raktažodžiai: misoprostolis, prostaglandinai, gimdymo sužadinimas, nesubrendęs gimdos kaklelis, gimdymo būdas.

\begin{abstract}
Santrauka
Vilniaus gimdymo namuose buvo atlikta retrospektyvioji 187 ligos istorijų analizè moterų, kurioms gimdymas buvo sužadintas prostaglandinais, skiriant misoprostolio tabletes ị makštị arba po liežuviu. Tiriamosios suskirstytos ị dvi grupes: moterys, kurioms buvo gimdymas sužadintas skiriant misoprostolio tabletes per makštị (67 moterys) bei moterys, kurioms sužadinimas buvo atliktas skiriant misoprostolio tabletes po liežuviu (120 moterų). Grupès buvo lygintos pagal mekonijaus buvimą vaisiaus vandenyse, gimdymo baigtis ir gimdymo užbaigimo būdo indikacijas. Rezultatai. Lyginant tiriamuju grupes, moterų, kurioms misoprostolis buvo skirtas ị makštį, vaisiaus vandenų su mekonijumi dažnis yra net 9,85 proc. didesnis, o cezario pjūvio operacijų skaičius 3,76 proc. mažesnis nei moterų, kurioms misoprostolis buvo skirtas po liežuviu. Tačiau šie skirtumai yra statistiškai nereikšmingi. Abiejose grupèse daugiausia moterų gimdè natūraliuoju būdu. Instrumentinių gimdymų užbaigimo kiekis bei indikacijos jam reikšmingai nesiskyrẻ tarp abiejų grupių. Lyginant cezario pjūvio operacijų dažnį tarp nesužadintų gimdymų bei sužadintų misoprostolio pagalba statistiškai reikšmingo skirtumo neaptikta.
\end{abstract}

\section{Ivadas}

Gimdymo sužadinimas - tai dirbtinai sukelti gimdos susitraukimai prieš savaiminio gimdymo pradžią, siekiant užbaigti nėštumą natūraliu būdu. Tai viena dažniausių procedūrų akušerijoje. Kai gimdos kaklelis nebrandus, didejja nèštumo užbaigimo cezario pjūvio operacijos tikimybè. Gimdos kaklelio subrendimas - vienas svarbiausių gimdymo sužadinimo sekmès rodiklių. Esant nebrandžiam gimdos kakleliui, gimdymo sužadinimas atliekamas misoprostolio pagalba.
Misoprostolis yra sintetinis PGE1 analogas, kuris buvo sukurtas skrandžio opoms, sukeltoms NVNU, gydyti. Vèliau buvo pastebèta bei klinikiniais tyrimais ịrodyta, kad misoprostolis turi daug teigiamų pašalinių efektų, dèl to vaistas gali būti naudojamas daug plačiau [1]. Akušerijoje jis plačiai naudojamas dèl jo gebejjimo subrandinti gimdos kakleli, skatinti gimdos susitraukimus, stabdyti pogimdymini kraujavimą. Jis pakankamai patogus vartoti, nes yra stabilus kambario temperatūroje, nebrangus, turi daug vartojimo būdų: gali būti geriamas, dedamas po liežuviu, ị makštį, ị tiesiąją žarną. Priklausomai nuo vaisto vartojimo būdo, skiriasi vaisto farmakokinetiniai rodikliai [2]. Žinoma, jog vartojant misoprostoli per burną, didžiausia veikliujų metabolitų koncentracija kraujo serume susidaro per $30 \mathrm{~min}$., tai yra greičiau lyginant su vaginaliniu būdu, kuris savo didžiausią koncentraciją pasiekia per 1 val. Tačiau ir pasišalina iš kraujotakos geriamas misoprostolis greičiau - per 2-3 val., kai ị makštị skiriamas misoprostolis išlieka kraujotakoje daugiau kaip 4 val. [3].

Pagal Lietuvoje galiojančią SAM patvirtintą 2014-ųjų metų metodiką „Gimdymo sužadinimas“, esant nesubrendusiam gimdos kakleliui (Bishop <6) misoprostolis gimdymo veiklai sužadinti gali būti skiriamas ị makšti - po $25 \mu \mathrm{g}$ kas 6 val. iki 6 dozių, per burną - po $50 \mu \mathrm{g}$ kas 4 val. arba po $25 \mu \mathrm{g}$ kas 2 val., bei po liežuviu - po $50 \mu \mathrm{g}$ kas 4 val. iki 6 dozių [4].

Šio tyrimo tikslas - palyginti gimdymų, sužadintų skiriant prostaglandinus per burną ir sužadintų gimdymų, skiriant prostaglandinus per makštį, komplikacijas, baigtis ir gimdymo užbaigimo būdus.

\section{Metodika}

Tyrimas buvo atliktas Všt Vilniaus gimdymo namuose - antroje pagal gimdymų skaičių ligoninèje Vilniuje. Retrospektyviai analizuoti nuo 2017 sausio 1 d. iki 2018 gruodžio $31 \mathrm{~d}$. něščiųų medicininių dokumentų duomenys. Iš gimdymo istorijų buvo renkami duomenys apie nèštumo ir gimdymo eigą bei gimdymo baigtis. İ tyrimą buvo įtrauktos 
187 moterys, kurios atitiko šiuos kriterijus: išnešiotas nėštumas, galvinè pirmeiga, vienvaisis gimdymas, gimdymas sužadintas prostaglandinais, skiriant misoprostolio tabletes ị makštį bei per burną. Gimdymo veiklos sužadinimas buvo atliekamas pagal $2014 \mathrm{~m}$. SAM patvirtintą metodiką ,Gimdymo sužadinimas“. Nuo 2017 m. sausio 1 d. iki 2017 m. gruodžio $31 \mathrm{~d}$. gimdymas buvo sužadinamas $25 \mu \mathrm{g}$ misoprostolio tabletes dedant ị makšti kas 4-6 val. - iš viso 67 moterims. Nuo 2018 m. sausio 1d. iki 2018 m. gruodžio $31 \mathrm{~d}$. gimdymas buvo sužadinamas $50 \mu \mathrm{g}$ misoprostolio tabletemis, kurios buvo vartojamos po liežuviu kas 4 val. iš viso 120 moterų. Leidimas atlikti tyrimą buvo gautas iš Gimdymo namų etikos komisijos.

Tiriamosios suskirstytos ị dvi grupes: moterys, kurioms buvo gimdymas sužadintas skiriant misoprostolio tabletes per makštį, bei moteris, kurioms sužadinimas buvo atliktas skiriant misoprostolio tabletès po liežuviu. Grupès buvo lygintos pagal mekonijaus buvimą vaisiaus vandenyse, gimdymo baigtis ir gimdymo užbaigimo būdo pasirinkimo priežastis.

Statistinè duomenų analizė buvo atlikta naudojant SPSS for Windows ir Excel for Windows programas. Kokybiniu požymių statistinis ryšys vertintas Pirsono (Pearson) arba tiksliuoju Fišerio (Fisher) kriterijumi. Vertinant statistini patikimumą, skirtumas laikytas statistiškai reikšmingu, kai $\mathrm{p}<0,05$.

\section{Rezultatai}

Tiriamuoju laikotarpiu Vš İ Vilniaus gimdymo namuose gimde 6089 moterų. 2017 metais buvo priimta 3147 gimdymų, iš kurių 2,13 proc. $(n=67)$ gimdymų buvo sužadinti misoprostoliu. 2018 metais buvo priimta 2942 gimdymų, iš jų 4,08 proc. $(\mathrm{n}=120)$ sužadinti misoprostoliu.

$2017 \mathrm{~m}$. gimdymai buvo sužadinami $25 \mathrm{mcg}$ misoprostolio tabletes dedant ị makštị kas 4-6 val. Po sužadinimo 70,15 proc. $(n=47)$ gimdyvių vaisiaus vandenys buvo bespalviai ir 29,85 proc. $(n=20)$ gimdyvių vaisiaus vandenys buvo su mekonijumi. Iš 67 gimdymų natūraliais gimdymo takais pagimdè 67,16 proc. $(n=45), 17,91$ proc. $(n=12)$ gimdymu buvo baigti cezario pjūvio operacijos (CPO) pagalba, 8,96

1 lentelè. Indikacijos instrumentiniam gimdymui užbaigti.

\begin{tabular}{|l|c|c|}
\hline & \multicolumn{2}{|c|}{ Metai } \\
\hline $\begin{array}{l}\text { Indikacijos instrumenti- } \\
\text { niam gimdymo užbaigimui }\end{array}$ & 2017 & 2018 \\
\cline { 2 - 3 } $\begin{array}{l}\text { Vaisiaus širdies plakimo } \\
\text { dažnio anomalijos/vaisiaus } \\
\text { hipoksija }\end{array}$ & $6(8,96 \%)$ & $13(10,83 \%)$ \\
\hline $\begin{array}{l}\text { Antrinè gimdos inercija/už- } \\
\text { trukęs vaisiaus išstūmimo } \\
\text { laikotarpis }\end{array}$ & $4(5,97 \%)$ & $3(2,50 \%)$ \\
\hline
\end{tabular}

proc. $(\mathrm{n}=9)$ vakuumo ekstrakcijos pagalba, 1,49 proc. $(\mathrm{n}=1)$ replių pagalba.

$2018 \mathrm{~m}$. gimdymai buvo sužadinami $50 \mathrm{mcg}$ misoprostolio tabletemis, kurios buvo vartojamos per burną kas 4 val. Net 80,00 proc. $(n=96)$ gimdyvių vaisiaus vandenys buvo bespalviai ir tik 20 proc. $(n=24)$ moteru vaisiaus vandenys buvo su mekonijumi. Sužadintų něštumų baigtys: 65,83 proc. $(\mathrm{n}=79)$ natūralių gimdymų, 21,67 proc. $(\mathrm{n}=26) \mathrm{CPO}$, 10,83 proc. $(n=13)$ vakuumo ekstrakcijų, 1,67 proc. $(n=2)$ ekstrakcijų su replèmis.

Lyginant tiriamujjų grupes (2017-ujjų ir 2018-uјjų metų), 2018 metais perejus prie geriamo misoprostolio gimdymui sužadinti, net 9,85 proc. sumažějo vaisiaus vandenų su mekonijumi dažnis, tačiau šis skirtumas nèra statistiškai reikšmingas, $p=0,151$. 3,76 proc. išaugo $C P O$ skaičius, $p=0,388$, taigi skirtumas statistiškai nereikšmingas. Instrumentinių gimdymų užbaigimo skaičius nesikeite tyrimo metu. Indikacijos instrumentiniam gimdymo užbaigimui (1 lentelè) ir CPO (2 lentelè) reikšmingai nesiskyrè tarp abiejų grupių.

2017-ais m. Všİ Gimdymo namuose CPO dažnis tarp nesužadintų gimdymų buvo 16,25 proc., 2018-ais m. 17,23 proc. Lyginant juos su misoprostoliu sužadintų atitinkamų metų grupėmis statistiškai reikšmingo skirtumo neaptikta.

\section{Rezultatu aptarimas}

Šio tyrimo rezultatai rodo, kad nèra statistiškai patikimo CPO dažnio skirtumo tarp misoprostolio vartojimo per burną ir ị makštį, siekiant sužadinti gimdymą esant nepasiruošusiam gimdos kakleliui. Nepaisant to, skiriant geriamą misoprostolị, procentiškai išreikštas CPO dažnio skirtumas yra nemažas, apie 4 proc. Panaši situacija aprašoma ir kitų autorių. Shetty ir bendradarbių tyrime CPO dažnis vaginaliai skirto misoprostolio grupejje yra 22,8 proc., o geriamo misoprostolio grupeje 24,6 proc.[1]. How ir bendradarbiu tyrime atitinkamai 17 proc. ir 33 proc. [2]. Jindal ir bendra-

2 lentelè. Indikacijos cezario pjūvio operacijai.

\begin{tabular}{|l|c|c|}
\hline \multirow{2}{*}{ Indikacijos CPO } & \multicolumn{2}{|c|}{ Metai } \\
\cline { 2 - 3 } & atvejai, n (\%) & atvejai, n (\%) \\
\hline Distocija & $1(1,49 \%)$ & $5(4,17 \%)$ \\
\hline $\begin{array}{l}\text { Atloštinė vaisiaus pirmeiga/ne- } \\
\text { taisyklinga vaisiaus pozicija/ } \\
\text { dalinis galvos pasisukimas }\end{array}$ & $1(1,49 \%)$ & $2(1,67 \%)$ \\
\hline $\begin{array}{l}\text { Itariama nestabili vaisiaus } \\
\text { būklè }\end{array}$ & $5(7,46 \%)$ & $13(10,83 \%)$ \\
\hline $\begin{array}{l}\text { Nepavykęs gimdymo veiklos } \\
\text { sužadinimas }\end{array}$ & $3(4,48 \%)$ & $5(4,17 \%)$ \\
\hline Neprogresuojantis gimdymas & $2(2,99 \%)$ & $2(3,50 \%)$ \\
\hline
\end{tabular}


darbiu atliktame dvigubai aklame randomizuotame tyrime geriamo misoprostolio grupejjè CPO dažnis buvo didesnis nei 15 proc., lyginant su vaginaliai vartoto misoprostolio grupe [5].

Anksčiau paskelbtų panašių tyrimų rezultatų duomenys leidžia manyti, kad skiriant misoprostolị per makšti didejja žalių vaisiaus vandenų dažnis $[6,7]$. Mūsų atliktame tyrime stebima panaši tendencija. İ makštį skirto misoprostolio grupejjè mekonijumi suterštų vandenų buvo 9,85 proc. daugiau nei geriamo misoprostolio grupeje.

Mūsų atliktame tyrime abiejose grupèse dažniausiai nèštumas buvo užbaigiamas natūraliuoju būdu: grupeje su misoprostoliu, skirtu į makštį 67,16 proc. $(n=45)$, geriamo misoprostolio grupeje 65,83 proc. $(n=79)$, panašūs yra ir kitų anksčiau atliktų tyrimų duomenys $[1,2,5,6]$. Abiejose grupése $\sim 10-11$ proc. néštumų užbaigiami instrumentų pagalba. Nepriklausomai nuo misoprostolio skyrimo būdo, dažniausia indikacija CPO buvo vaisiaus hipoksija, kas sutampa su kitų atliktų tyrimų duomenimis $[1,5,6]$.

\section{Išvados}

1. Remiantis tyrimo rezultatais galima teigti, kad tarp gimdymui sužadinti skirto $25 \mu \mathrm{g}$ ị makšti misoprostolio bei $50 \mu \mathrm{g}$ geriamo misoprostolio, cezario pjūvio operacijų dažnio statistiškai patikimo skirtumo nèra.

2. Taip pat nèra statistiškai patikimo žalių vaisiaus vandenų radimo dažnio padidejjimo skiriant misoprostolị i makštį.

3. Abu misoprostolio skirimo būdai yra patikimi naudoti, nesiskiria jų nėštumo baigčių rezultatai.

\section{Literatūra}

1. Shetty A, Danielian P, Templeton A. A comparison of oral and vaginal misoprostol tablets in induction of labour at term. $\mathrm{Br}$ J Obstet Gynaecol 2001;108:1-6.

https://doi.org/10.1016/S0306-5456(00)00073-5

2. How HY, Leasebevrge L, Khoury JC. et al. A comparison of various routes and dosages of misoprostol for cervical ripening and the induction of labour. Am J Obstet Gynaecol 2001;185:911-5.

https://doi.org/10.1067/mob.2001.117358

3. Drug Review. Misoprostol an old drug, new indications. Br J Postgrad Med 2002; 48 (4): 336-9.
4. Sveikatos Apsaugos Ministerijos internetinis puslapis. Metodika "Gimdymo sužadinimas", 2014 m. Adresas: https://sam.lrv. lt/lt/veiklos-sritys/programos-ir-projektai/sveicarijos-paramosprograma/akuserijos-ir-neonatologijos-diagnostikos-ir-gydymo-metodikos/akuserijos-diagnostikos-ir-gydymo-metodikos .

5. Jindal P, Avasthi K, Kaur M. A comparison of vaginal vs. oral misoprostol for induction of labour-double blind randomized trial. J Obstet Gynaecol India 2011;61(5):538-542.

https://doi.org/10.1007/s13224-011-0081-0

6. Bartusevičius A., Barčaitė E., Krikštolaitis R., Gintautas V. Gimdymui sužadinti po liežuviu ir ị makštị vartojamo misoprostolio palyginimas klinikinių atsitiktinių imčių tyrimu. Lietuvos akušerija ir ginekologija, 2006; 9(1):16-21.

7. Gudavičius A., Mačiulevičienė R. Gimdymo sužadinimas misoprostoliu. Lietuvos akušerija ir ginekologija, 2003; 6(3):177180.

\section{THE COMPARISON OF SUBLINGUAL AND VAGINAL MISOPROSTOL FOR LABOUR INDUCTION}

K.Mačiulienė, D.Variakojienė, A.Boukun, J.Andreičik

Key words: misoprostol, prostaglandin, labour induction, unripe cervix, labour.

Summary

The aim. To compare labour outcomes of vaginal and sublingual Prostaglandin tablets used for labour induction. Methods. Retrospective analysis of 187 women with inducted labour by vaginal or sublingual misoprostol tablets, who gave labour in Vilnius Maternity Hospital. Women were separated in two groups: administered vaginal misoprostol (67 women) and sublingual misoprostol (120 women). The comparison was made by estimating quantity of cases with meconeum in amniotic fluid, labour outcomes and labour termination indications. Results. Patients administered vaginal misoprostol compared with buccal misoprostol had 9,85\% less frequent meconium in amniotic fluid and 3,76 \% bigger Caesarian section rate. Although these differences between two groups are not statistically significant. In both groups more women gave birth naturally. Indications and quantity of instrument assisted labour were similar in both groups. There was no statistically significant difference in Caesarian section rate between misoprostol inducted and no inducted labours.

Correspondence to: alesja.bovkun@gmail.com

Gauta 2019-03-19 